\title{
Cytotoxic attributes of antiviral plants rich in polyphenolic and volatile compounds
}

Tomas Drevinskas ${ }^{1}$,

Rūta Mickiené ${ }^{1}$,

Audrius Maruška ${ }^{1^{*}}$,

Mantas Stankevičius ${ }^{1}$,

Nicola Tiso ${ }^{1}$,

Algirdas Šalomskas ${ }^{2}$

Raimundas Lelešius ${ }^{3,2}$,

Agneta Karpovaité2,

\section{Ona Ragažinskiene் $\dot{~}^{4}$}

${ }^{1}$ Faculty of Natural Sciences, Instrumental Analysis Open Access Centre,

Vytautas Magnus University,

Vileikos St. 8, 44404 Kaunas, Lithuania

${ }^{2}$ Department of Veterinary Pathobiology,

Veterinary Academy of Lithuanian University

of Health Science,

Tilžès St. 18, 47181 Kaunas, Lithuania

${ }^{3}$ Institute of Microbiology and Virology,

Veterinary Academy of Lithuanian University

of Health Science,

Tilžès St. 18, 47181 Kaunas, Lithuania

${ }^{4}$ Sector of Medicinal Plants,

Kaunas Botanical Garden

of Vytautas Magnus University,

Ž. E. Žilibero St. 6 ,

46324 Kaunas, Lithuania
The application of natural products for treatment and prevention of various diseases is becoming more important. Not only antibacterial natural preparations are being developed, but also antiviral natural products are investigated. There are two main problems in such investigations: (i) special chemical analysis and data analysis methods have to be used, (ii) not only antiviral effect has to be taken into account, but also cytotoxic and other unwanted effects. In this work, a combination of separation methods (capillary electrophoresis and gas chromatography), spectrophotometric methods, data mining/data analysis methods (hierarchical clusterization, multidimensional scaling and classification and regression tree induction) for clarifying chemical attributes in cytotoxic plant extracts was applied. The selected plants belonged to families: (i) Lamiaceae, (ii) Asteraceae and (iii) Fabaceae. Most cytotoxic were Agastache foeniculum Pursh. Kuntze. and Salvia officinalis L. extracts. Least cytotoxic were Perilla frutescens L. and Satureja Montana L. extracts. The tendency of cytotoxic extracts having abundant concentrations of medium and low electrophoretic mobility cations was clarified.

Keywords: chemometrics, capillary electrophoresis, gas chromatography, spectrophotometrics, antiviral plants, data mining

*Corresponding author. Email: audrius.maruska@vdu.lt 


\section{INTRODUCTION}

Medicinal plants and products derived from medicinal plants are top priority among phytotherapy scientists [1]]. Such products are interesting due to the fact that they are from the source of natural origin [1]. Bactericidal and bacteriostatic effects of plant extracts are widely investigated and known [2]. Antiviral effects are also reported in the literature [3]. Despite all these beneficial effects of the medicinal plants, it must be taken into account that plant extracts possess negative effects: (i) toxic, (ii) mutagenic, (iii) carcinogenic, (iv) hallucinogenic, (v) allergic and other unwanted effects [4]. It is known in the literature that numerous lethal and potentially lethal plants exist [5]. Utmost care must be taken developing pharmaceutical preparations due to the fact that residual toxic substances left in the developed products can lead to serious consequences [ $[$ ].

Separation methods are superior over standard electrochemical, or spectrophotometric methods, since the separation step is combined with spectrometric, electrochemical or other physicochemical detection methods. Separation methods can clarify multiple factors, or peaks in a single run, therefore such means can be treated as multidimensional information providing methods [6]. Among them capillary electrophoresis, gas chromatography and liquid chromatography are dominating in phytochemical investigations [月, 8]. Capillary electrophoresis is a method that is used for separation of soluble charged, or chargeable analytes [9]. Gas chromatography is mainly used for separation of volatile compounds [10]. Liquid chromatography in the reversed phase mode is mainly used for separating substances according to their different pollarity [11]. Spectrophotometric assays are also used. Such methods are capable of determining certain groups of compounds in the complex mixtures and such techniques help in screening the substances of interest [10, 11].

Multiple data analysis methods exist for clarifying complex tendencies. Currently, machine learning and data mining methods are gaining popularity due to the fact that computational power of the computers has increased significantly since such methods were invented [12]. Deep neural networks and their modifications are used in computational biology [13]. Decision tree methods are capable of classifying various cases and even bio-products [14]. The k-Nearest-Neighbor classification has been used in the past and is still widely used now for biological and biochemical investigations [15]. In some cases subjective features have to be evaluated and expressed numerically and such approach has already been applied for evaluation of kiwifruit natural coatings [16]. Recently a methodology for determination of antiviral attributes in the plant extracts has been published [17]. It was determined that plant extracts contained phenolic compounds that were related to antiviral activity in the plant extracts. Additionally, amine group containing substances were separated suggesting that they are indirectly related to antiviral activity in medicinal plant extracts [17].

The aim of this work was to clarify what attributes in potentially antiviral plants possess cytotoxic activity.

\section{EXPERIMENTAL}

\section{Chemicals}

Acetic acid was purchased from Reachem (Slovakia). Methanol $(\mathrm{MeOH})(99.9 \%)$, acetonitrile (ACN) (99.9\%), 2,2-diphenyl-1-picrylhydrazyl (DPPH), Folin-Ciocalceau reagent $2 \mathrm{~N}$ and rutin (95\%) and MTT reagent were purchased from Sigma-Aldrich (Germany), dimethyl sulfoxide (DMSO) was from Carl Roth (Germany). Aluminum chloride was from ROTH (USA). Sodium hydroxide $(99.0 \%)$ was purchased from Reachem (Slovakia), ethanol (EtOH) (96\%) was from Sigma-Aldrich (Germany). Bidistilled water was produced in the laboratory using a Fistreem Cyclon bidistillator (UK). Detector helium gas (detector grade) for gas chromatography was from AGA, Latvia.

\section{Instrumentation}

The capillary electrophoresis (CE) system HP3DCE was used for analysis of plant extracts. The CE system had a contactless conductivity detector integrated following the previously published procedures [18, 19]. The gas chromatography-mass spectrometry system GC2010 and GCMS-QP2010 (Shimadzu, Japan) was used for the analysis of volatiles. The samples were handled using an automatic injector AOC-5000 from Shimadzu (Japan). The capillary column RTX-5MS, length $30 \mathrm{~m}$, ID $0.25 \mathrm{~mm}$, film thickness $0.25 \mu \mathrm{m}$ (Restek, USA), was used for the separation of volatile compounds.

The Milton Roy Spectronic 1201 Spectrophotometer was used for photometric assays.

\section{Sample preparation}

Medicinal plants rich in volatile and polyphenol compounds were selected for the research [20]. The set of selected plants was previously investigated for antiviral effects [17]. The list of plants is the following: Saturea montana L. (S. montana), Chamaemelum nobile $\mathrm{L}$. (Ch. nobile), Perilla frutescens L. Britton. (P. frutescens), Agastache foeniculum (Pursh) Kuntze (A. foeniculum), Origanum vulgare L. (O. vulgare), Mentha piperita L. (M. piperita), Geranium macrorrhizum L. (G. macrorrhizum), Melissa officinalis L. (M. officinalis), Angelica archangelica L. (aerial part) (A. archangelica aerial part), Angelica archangelica L. (roots) (A. archangelica roots), Thymus vulgaris L. (T. vulgaris), Hyssopus officinalis L. (H. officinalis), Nepeta cataria L. (N. cataria), Echinacea purpurea L. Moench. (E. purpurea), Salvia officinalis L. (S. officinalis) and Desmodium canadence L. DC. (D. canadence). 
Extracts were prepared in ambient temperature (ca. $20^{\circ} \mathrm{C}$ ). $0.5 \mathrm{~g}$ of ground raw material of the plant was added to a $20 \mathrm{ml}$ vial and was extracted using a $10 \mathrm{ml}$ of $40 \%(\mathrm{v} / \mathrm{v}) \mathrm{EtOH} /$ water mixture. The extraction lasted for $24 \mathrm{hrs}$ in an orbital shaker at $180 \mathrm{rpm}$.

\section{Analytical procedures and cytotoxicity evaluation} Capillary electrophoresis-contactless conductivity detection. Capillary electrophoresis-contactless conductivity detection (CE-C4D) was performed following the previously published, slightly modified procedure, where analysis was done in acidic media [21]. Separation was carried out using a $0.5 \mathrm{M}$ acetic acid background electrolyte $\left(\mathrm{pH} \mathrm{2.5)}\right.$ at $40^{\circ} \mathrm{C}$. Hydrodynamic injection was used $(50 \mathrm{mbar} \times 40 \mathrm{~s})$. Separations were done in the fused silica capillary: inner diameter $50 \mu \mathrm{m}$, outer diameter $365 \mu \mathrm{m}$, total length $50 \mathrm{~cm}$, effective length $38 \mathrm{~cm}$. Prior to the analysis, the capillary was washed with the $0.1 \mathrm{M} \mathrm{NaOH}$ solution and the background electrolyte.

Gas chromatography-mass spectrometry. The samples were injected in a gas chromatography injection port using a micro syringe, $1 \mu \mathrm{l}$ was injected using a split mode at the split ratio $1: 10$. The linear velocity of the mobile phase was set to $1.2 \mathrm{ml} / \mathrm{min}$ in the column. Temperature gradient conditions were set starting from $60^{\circ} \mathrm{C}$ and maintained for $3 \mathrm{~min}$, then rising to $150^{\circ} \mathrm{C}$ at $5^{\circ} \mathrm{C} / \mathrm{min}$ and from 150 to $180^{\circ} \mathrm{C}$ at $20^{\circ} \mathrm{C}$ and maintaining the final temperature for $3 \mathrm{~min}$. The injection port and the column interface were set to 240 and $260^{\circ} \mathrm{C}$, respectively. The ion source was heated to $260^{\circ} \mathrm{C}$. The electron ionization mode was used for mass spectrometry with $70 \mathrm{eV}$ ionization energy. Masses were scanned in the range from 30 to $400 \mathrm{~m} / \mathrm{z}$.

Spectrophotometric analysis. Determination of total phenolic content (TPC). TPC was determined following the previously optimized Folin-Ciocalteu method [10, 22]. $1.0 \mathrm{ml}$ of the sodium carbonate $(4 \%, \mathrm{pH} 10)$ solution was mixed with $0.033 \mathrm{ml}$ of the sample and $0.033 \mathrm{ml}$ of the Folin-Ciocalteu reagent $(2 \mathrm{~N})$. The reaction lasted for $30 \mathrm{~min}$ at $30^{\circ} \mathrm{C}$ and after the reaction absorbance was measured at $760 \mathrm{~nm}$ wavelength. The Rutin standard solution was used for the calibration and the determined amounts were expressed in rutin equivalents $(\mathrm{RE} \mathrm{mg} / \mathrm{ml})$. The calibration range was $0.01-1.00 \mathrm{mg} / \mathrm{ml}$.

Determination of total flavonoid content (TFC). TFC was determined following the previously optimized procedure [10, 22]. The stock solution was prepared and it consisted of $60.0 \mathrm{ml}$ methanol, $3.0 \mathrm{ml}$ acetic acid (33\%), $12.0 \mathrm{ml}$ hexamethylenetetramine (5\%), $9.0 \mathrm{ml}$ aluminum chloride $(10 \%)$ and $60.0 \mathrm{ml}$ bidistilled water. The sample $(0.04 \mathrm{ml})$ was added to a $0.960 \mathrm{ml}$ stock solution. The reaction lasted for $30 \mathrm{~min}$ at $+2^{\circ} \mathrm{C}$. After the reaction absorbance was measured at $407 \mathrm{~nm}$. The calibration range was $0.01-1.00 \mathrm{mg} / \mathrm{ml}$.

Determination of radical scavenging activity (RSA). RSA was determined following the previously optimized procedure [10,22]. The sodium acetate buffer $(0.1 \mathrm{M})$ was prepared ( $\mathrm{pH}$ 5.5). In $125 \mathrm{ml} \mathrm{ACN}$ with $125 \mathrm{ml} \mathrm{MeOH}$ $10 \mathrm{mg}$ DPPH was dissolved. The obtained organic mixture was mixed with the acetate buffer (1:1). The absorbance was recorded at $515 \mathrm{~nm}$ wavelength and the DPPH reagent was diluted with ACN, so that the absorbance showed 0.6. The sample $(0.025 \mathrm{ml})$ was added to the DPPH reagent $(1.0 \mathrm{ml})$. After $15 \mathrm{~min}\left(30^{\circ} \mathrm{C}\right)$ the absorbance was measured at $515 \mathrm{~nm}$. The calibration range was $0.01-0.50 \mathrm{mg} / \mathrm{ml}$.

Cytotoxicity evaluation. The cytotoxic concentration $\left(\mathrm{CC}_{50}\right)$ was determined for each extract on Vero cells using the MTT assay [23]. First, cells were seeded at a concentration of $1 \times 10^{4}$ cells/well in a 96 -well plate and grown at $37^{\circ} \mathrm{C}$ for 1 day. The assay was performed in octuplicate for each extract. After $72 \mathrm{hrs}$ the MTT reagent $(10 \mu \mathrm{l}, 5 \mathrm{mg} / \mathrm{ml})$ was added and incubated for $4 \mathrm{hrs}$ at $37^{\circ} \mathrm{C}$. Then $100 \mu \mathrm{l}$ dimethyl sulphoxide (DMSO) was added to each well and the plates were placed on the shaker for $5 \mathrm{~min}$. The absorbance of each well was measured at $620 \mathrm{~nm}$ in a microplate reader (Multiskan $^{\text {tax }}$ FC Microplate Photometer) and the percentage of cell survival was calculated. Finally, dose-response curves were plotted to enable the calculation of $\mathrm{CC}_{50}$ that causes lysis and death of $50 \%$ of cells.

\section{Data analysis}

Data normalization and conditioning. The data points were normalized following the previously published procedure [17]. The average of the dataset is subtracted from the data point and the difference is divided by the standard deviation of the dataset. Using this technique, the statistical average is transformed to 0 and the standard deviation $(\sigma)$ is transformed to 1 . Such data normalization helps avoiding dimensionality and weight difference of the determined chemical parameters in data analysis.

Separation data segmentation. Electropherograms and gas-chromatograms were segmented following the previously published procedure: (i) the pre-electroosmotic region of the electropherograms was sub-divided into 3 segments including high migration velocity, medium migration velocity and low migration velocity peaks (cations in the pre-electroosmotic region) of the electropherograms; (ii) the chromatograms were sub-divided into 3 segments including high (5-9 min), medium (9-16 min) and low (16-24 min) volatility substances; (iii) the peak areas were summed in the segment; (iv) peak sums of the segments were used for further data analysis.

Hierarchical clusterization. Hierarchical clusterization was performed using the software Rstudio [24]. The dataset was imported into the software and for clusterization the method of Euclidean distance matrix calculation was used.

Classification and regression tree induction. The classification and regression tree (CART) decision tree induction was performed using the software Rstudio with the additional package rpart 25.

Multidimensional scaling (MDS) [26]. MDS was performed using the Rstudio software. For calculating 
the differences, the method of Euclidean distance was used. The function of MDS called cmdscale was applied and all dimensions were transported to two-dimension projections.

Method validation. Analytical method validation was done in accordance with the pharmaceutical method validation guidelines (ICHQ2R1) 27]. Calibration was performed using at least 6 different levels of concentration in the specified range. Precision and accuracy (expressed in the relative standard deviation) was evaluated from at least 5 different levels of concentrations performing a triplicate analysis.

\section{RESULTS AND DISCUSSION}

\section{Characterization of the extracts}

Cytotoxicity of the extracts was determined. It was found that the $\mathrm{CC}_{50}$ concentration was in the range between the 0.06 (A. foeniculum) to 0.77 (P. frutescens) dilution of the initial extract, where the lowest values were considered showing the highest cytotoxicity (low concentration is needed for cytotoxic action) and the highest values were considered showing the lowest cytotoxicity. The mean of the dataset was 0.396 and it was decided to classify plant extracts according to the $\mathrm{CC}_{50}$ mean value: the extracts possessing higher $\mathrm{CC}_{50}$ than the mean (0.396) were classified as non-cytotoxic and the extracts possessing lower $\mathrm{CC}_{50}$ than the average were classified as cytotoxic. Cytotoxic and noncytotoxic extracts were discretized attributing 0 to the non- cytotoxic class and attributing 1 to the cytotoxic class. Such discretization was used for latter experiments and mathematical calculations.

A chemical analysis of the extracts was performed. Different dimensions of chemical attributes were obtained: 11 dimensions corresponding to the chemical attributes and 1 dimension corresponding to the cytotoxicity class (total 12 dimensions). The results were represented in the Table. 1 st, 2nd and 3rd attributes corresponded to capillary electrophoresis peak segments and was in the range of 0.012 to $0.47 \mathrm{pF} \cdot s$. 4th, 5th and 6th attributes were spectrophotometric investigations: TPC, TFC and RSA correspondingly and ranged between 0.04 to $13.47 \mathrm{RE} \mathrm{mg} / \mathrm{ml}$. 7th attribute represented the total peak area of the gas chromatogram and was in the range between $1.1 \cdot 10^{7}$ to $9.1 \cdot 10^{8}$ relative area units (RAU). 8th attribute represented the number of peaks in the gas chromatogram. The lowest number (19) of peaks was found in the P. frutescens extract and the highest number of peaks (47) was found in $S$. montana extract.9th, 10th and 11th attributes represented segments of gas chromatograms and ranged between 0 to $3.5 \cdot 10^{8} \mathrm{RAU}$.

\section{Chemical attribute selection for cytotoxic activity}

An additional column of the class (cytotoxic - 1 and noncytotoxic -0 ) was added to the dataset in the Table. Some values between the columns differed by 10 decades therefore normalization was performed and this procedure ranged over all values so that the mean of the column was

Table. Representation of chemical analysis attributes of different plant extracts

\begin{tabular}{|c|c|c|c|c|c|c|c|c|c|c|c|}
\hline Plant & 1 & 2 & 3 & 4 & 5 & 6 & 7 & 8 & 9 & 10 & 11 \\
\hline Dimension & pF.s & pF.s & pF.s & RE $\mathrm{mg} / \mathrm{ml}$ & $\mathrm{RE} \mathrm{mg} / \mathrm{ml}$ & $\mathrm{RE} \mathrm{mg} / \mathrm{ml}$ & RAU* & $\#$ & RAU* & RAU* & RAU* \\
\hline S. montana & 0.032 & 0.014 & 0.017 & 4.69 & 1.15 & 8.29 & $2.3 \mathrm{E}+08$ & 47 & $7.7 \mathrm{E}+07$ & $1.1 \mathrm{E}+08$ & $4.8 \mathrm{E}+07$ \\
\hline Ch. nobile & 0.089 & 0.123 & 0.125 & 2.05 & 0.39 & 1.95 & $4.7 \mathrm{E}+08$ & 39 & $1.2 \mathrm{E}+08$ & $3.5 \mathrm{E}+08$ & $0.0 \mathrm{E}+00$ \\
\hline P. frutescens & 0.047 & 0.077 & 0.012 & 2.88 & 0.95 & 3.11 & $8.6 \mathrm{E}+07$ & 19 & $1.5 \mathrm{E}+07$ & $6.4 \mathrm{E}+07$ & $7.5 \mathrm{E}+06$ \\
\hline A. foeniculum & 0.066 & 0.021 & 0.114 & 2.93 & 2.04 & 3.15 & $2.2 \mathrm{E}+08$ & 21 & $7.3 \mathrm{E}+07$ & $1.4 \mathrm{E}+08$ & $4.7 \mathrm{E}+06$ \\
\hline O. vulgare & 0.032 & 0.007 & 0.011 & 7.31 & 2.14 & 11.98 & $3.1 \mathrm{E}+08$ & 42 & $1.1 \mathrm{E}+08$ & $1.6 \mathrm{E}+08$ & $4.2 \mathrm{E}+07$ \\
\hline M. piperita & 0.060 & 0.069 & 0.037 & 5.48 & 2.23 & 8.72 & $9.1 \mathrm{E}+08$ & 40 & $2.1 \mathrm{E}+08$ & $6.4 \mathrm{E}+08$ & $5.7 \mathrm{E}+07$ \\
\hline $\begin{array}{c}\text { G. macrorrhi- } \\
\text { zum }\end{array}$ & 0.066 & 0.155 & 0.049 & 7.88 & 2.49 & 13.47 & $4.6 \mathrm{E}+07$ & 26 & $1.5 \mathrm{E}+07$ & $2.9 \mathrm{E}+07$ & $2.7 \mathrm{E}+06$ \\
\hline M. officinalis & 0.056 & 0.015 & 0.034 & 8.02 & 0.79 & 13.21 & $1.0 \mathrm{E}+08$ & 32 & $7.1 \mathrm{E}+07$ & $2.9 \mathrm{E}+07$ & $3.6 \mathrm{E}+06$ \\
\hline $\begin{array}{c}\text { A. archangelica } \\
\text { (aerial part) }\end{array}$ & 0.107 & 0.262 & 0.049 & 3.33 & 0.61 & 3.39 & $1.6 \mathrm{E}+08$ & 39 & $6.9 \mathrm{E}+07$ & $7.7 \mathrm{E}+07$ & $1.4 \mathrm{E}+07$ \\
\hline $\begin{array}{c}\text { A. archangelica } \\
\text { root }\end{array}$ & 0.472 & 0.274 & 0.027 & 0.75 & 0.04 & 0.33 & $4.1 \mathrm{E}+08$ & 33 & $3.0 \mathrm{E}+08$ & $5.4 \mathrm{E}+07$ & $5.8 \mathrm{E}+07$ \\
\hline T. vulgaris & 0.031 & 0.003 & 0.009 & 5.50 & 1.51 & 9.18 & $2.9 \mathrm{E}+08$ & 30 & $1.1 \mathrm{E}+08$ & $1.3 \mathrm{E}+08$ & $4.9 \mathrm{E}+07$ \\
\hline H. officinalis & 0.050 & 0.082 & 0.047 & 4.42 & 0.20 & 7.31 & $4.6 \mathrm{E}+08$ & 36 & $1.6 \mathrm{E}+08$ & $2.7 \mathrm{E}+08$ & $3.2 \mathrm{E}+07$ \\
\hline N. cataria & 0.075 & 0.046 & 0.137 & 1.53 & 0.43 & 1.25 & $2.2 \mathrm{E}+08$ & 28 & $4.5 \mathrm{E}+07$ & $6.7 \mathrm{E}+07$ & $1.1 \mathrm{E}+08$ \\
\hline E. purpurea & 0.107 & 0.121 & 0.116 & 5.56 & 0.55 & 5.37 & $2.4 \mathrm{E}+07$ & 21 & $1.1 \mathrm{E}+07$ & $1.3 \mathrm{E}+07$ & $6.1 \mathrm{E}+05$ \\
\hline S. officinalis & 0.042 & 0.028 & 0.032 & 5.66 & 1.79 & 7.65 & $5.9 \mathrm{E}+08$ & 30 & $2.6 \mathrm{E}+08$ & $3.2 \mathrm{E}+08$ & $1.8 \mathrm{E}+07$ \\
\hline
\end{tabular}

${ }^{*}$ RAU is relative area units. 
attributed to 0 and the standard deviation of the column was attributed to 1 . For attribute selection, what factors are important, the correlation matrix was calculated using all 12 normalized dimensions (Fig. 11).

As shown in Fig. 11, it was observed that medium and low electrophoretic mobility cations have a tendency to be more abundant in cytotoxic extracts than other compounds. This is interpreted by the fact that the correlation coefficient between the medium electrophoretic mobility cations and the class was 0.46 . Additionally, the correlation coefficient between the low electrophoretic migration cations and the class was 0.45. In the previous work, the medium and low electrophoretic mobility cations had a tendency to be less abundant in the extracts that possessed antiviral activity [17]. These compounds can be associated with amino group containing substances, or other positively chargeable organic cations: (i) free amino acids, (ii) biogenic amines, (iii) anthocyanins.

The correlation matrix showed that TPC and RSA attributes have a tendency to be less abundant in cytotoxic extracts. Even though there is a weak tendency, the extracts that possess a high amount of radical scavenging phenolic compounds have a lower probability to be toxic. What is more important, TPC and RSA provided a very high intercorrelation between attributes (0.97), therefore it is stated that both attributes possess the very same information and only one should be used for latter investigations. In the previous work, where antiviral attributes were clarified, it was observed that TPC and RSA abundancy values were significantly higher in antiviral extracts [17].

Interestingly, the attribute values that were obtained from the gas-chromatographic analysis of volatile compounds did not show a high level of correlation. It can be explained by the following presumptions: (i) the volatile compounds in the selected plant extracts do not possess cytotoxic activity, (ii) the cytotoxic activity of volatile compounds in the investigated plants is complex and needs more sophisticated data analysis means, (iii) the cytotoxic volatile compounds in the investigated plants are at low concentrations, therefore the correlation matrix does not show any dependencies and this investigation needs more sophisticated data analysis means.

For further analysis, 2nd, 3rd and 4th (medium and low electrophoretic mobility cations and TPC) attributes were selected and used.

\section{Data mining and chemometrics}

In order to confirm the findings described in the Chemical attribute selection for cytotoxic activity section, additional data mining techniques were performed: (i) hierarchical clusterization and (ii) multidimensional scaling. The hierarchical clusterization was performed using selected attributes and a cluster dendrogram was generated (Fig. 2). In the dendrogram it is visible that 2 clusters are formed: (i) non-toxic and (ii) toxic extracts. Three outliers were identified: (i) 2 were found in the non-toxic cluster (M. piperita and S. officinalis) and (ii) 1 was found in the toxic cluster (E. purpurea).

In the non-toxic cluster it is visible that $O$. vulgare and M. officinalis slightly differ from the rest data-points. In the toxic cluster it is visible that 3 sub-clusters are formed: (i) A. archangelica (roots and aerial part), (ii) Ch. nobile, A. foeniculum and N. cataria, (iii) G. macrorrhizum and D. canadence. Even though, there are 2 outliers in the nontoxic cluster, it is fully composed of Lamiaceae family plants therefore it can be presumed that the clusterization is also sensitive to differences of chemical attributes in different family plants.

\begin{tabular}{|c|c|c|c|c|c|c|c|c|c|c|c|c|}
\hline 1 & 2 & 3 & 4 & 5 & 6 & 7 & 8 & 9 & 10 & 11 & 12 & \\
\hline \multirow[t]{6}{*}{1.00} & 0.71 & -0.02 & -0.51 & -0.46 & -0.48 & 0.08 & -0.01 & 0.52 & -0.19 & 0.19 & 0.32 & 1 \\
\hline & 1.00 & 0.10 & -0.37 & -0.41 & -0.39 & -0.10 & -0.03 & 0.16 & -0.20 & -0.14 & 0.46 & 2 \\
\hline & & 1.00 & -0.31 & -0.24 & -0.38 & -0.19 & -0.38 & -0.33 & -0.08 & -0.08 & 0.45 & 3 \\
\hline & & & 1.00 & 0.60 & 0.97 & -0.18 & -0.04 & -0.27 & -0.06 & -0.37 & -0.31 & 4 \\
\hline & & & & 1.00 & 0.61 & 0.12 & -0.08 & -0.09 & 0.25 & -0.15 & 0.15 & 5 \\
\hline & & & & & 1.00 & -0.13 & 0.06 & -0.21 & -0.03 & -0.26 & -0.30 & 6 \\
\hline \multirow[t]{3}{*}{0.46} & \multirow{3}{*}{\multicolumn{5}{|c|}{$\begin{array}{l}\text { Moderate positive correlation } \\
\text { indicates cytotoxic effect }\end{array}$}} & 1.00 & 0.52 & 0.81 & 0.93 & 0.38 & 0.27 & 7 \\
\hline & & & & & & & 1.00 & 0.42 & 0.46 & 0.37 & -0.12 & 8 \\
\hline & & & & & & & & 1.00 & 0.57 & 0.33 & 0.27 & 9 \\
\hline \multirow{3}{*}{-0.31} & Weak & negativ & e corre & lation & & & & & 1.00 & 0.18 & 0.23 & 10 \\
\hline & $\begin{array}{l}\text { The ex } \\
\text { compo }\end{array}$ & $\begin{array}{l}\text { tracts } \\
\text { unds }\end{array}$ & posses & ing the & & & & & & 1.00 & 0.05 & 11 \\
\hline & are exl & pected & to be le & ss cytc & toxic & & & & & & 1.00 & 12 \\
\hline
\end{tabular}

Fig. 1. Correlation matrix of the chemical analysis attributes and cytotoxicity class. Attributes: (1) high, (2) medium, (3) low electrophoretic mobility cations, (4) TPC, (5) TFC, (6) RSA, (7) volatile compound peak area, (8) volatile peak count, (9) volatile peak area in the segment 4-9 min, (10) volatile peak area in the segment 9-16 min, (11) volatile peak area in the segment 16-24 min, (12) cytotoxicity class 


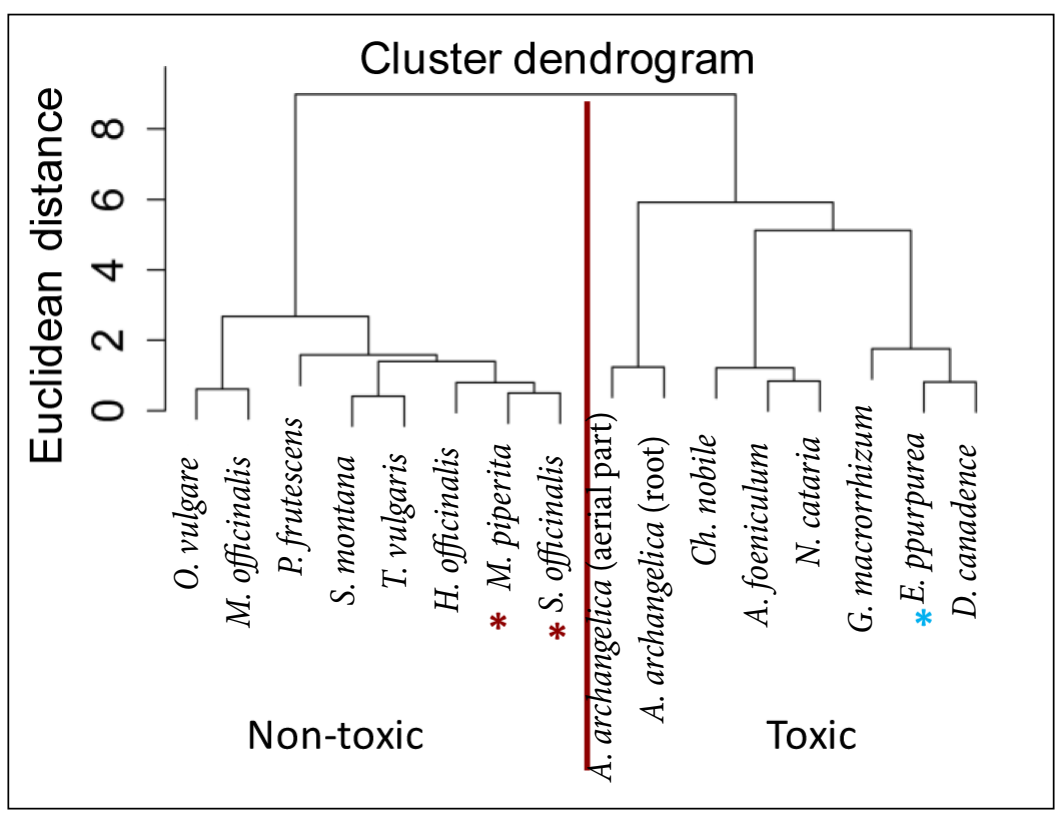

Fig. 2. The cluster dendrogram of medicinal plant extracts according to the selected attributes. ${ }^{*}$ Indication of the outliers: (dark red) cytotoxic, (light-blue) non-cytotoxic

In order to confirm the findings described in the dendrogram, multidimensional scaling calculations were performed using the selected attributes (Fig. 3). This technique is capable of reducing multiple components to the selected number of dimensions, therefore it is more understandable for the researchers [28]. In this research, the MDS technique provided two projections that were called Coordinate 1 and Coordinate 2. These values were dimensionless, but provided the key information of the clusters in the dataset (Fig. 3).

The same tendency as one observed in hierarchical clusterization dendrogram is visible in the MDS plot. The same outliers were observed: 6 - M. piperita, $14-E$. purpurea,
15 - S. officinalis and one additional - 7 - G. macrorrhi$z u m$. This is probably due to the fact that the representation of multidimensional data in only two dimensions is usually less accurate than the representation in a multidimensional format. On the other hand, the multidimensional format is less intuitive and often tendencies become invisible for the researchers.

The CART decision tree was generated using the selected attributes with the aim to inducing the rules that determine cytotoxic activity in the extracts (Fig. 4 A). The decision tree provided 2 clear rules. If (i) medium electrophoretic mobility cations have a lower normalized value than -0.83 , the extract is non-cytoxic. If medium

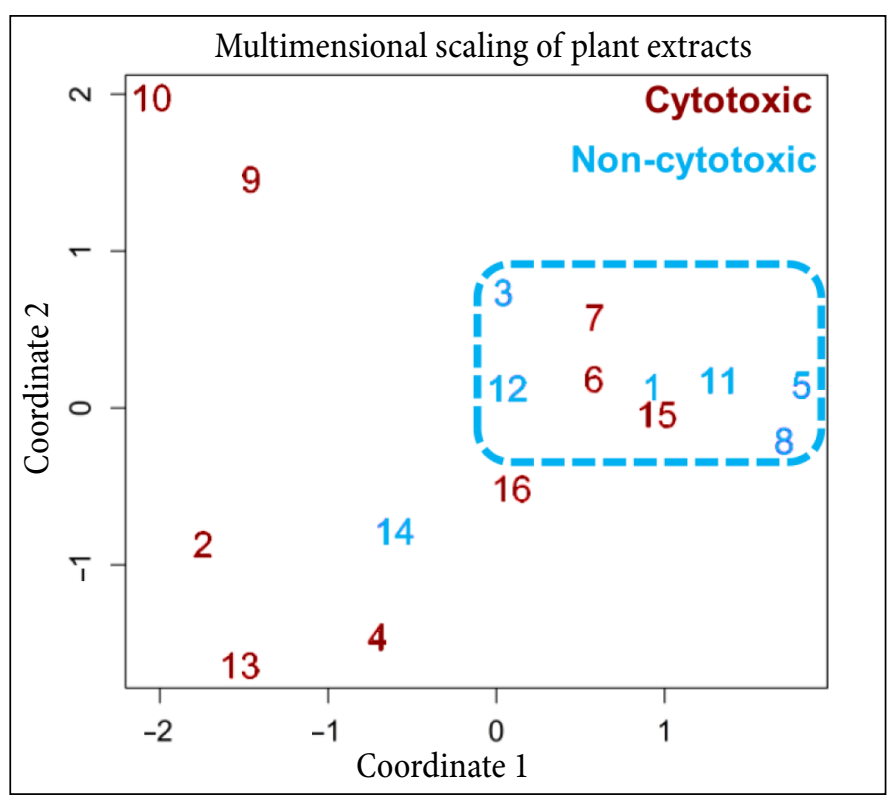

Fig. 3. Multidimensional scaling plot of the selected attributes of the plant extracts: (red) cytotoxic extracts and (blue) non-cytotoxic extracts. Extracts: S. montana (1), Ch. nobile (2), P. frutescens (3), A. foeniculum (4), Origanum vulgare (5), M. piperita (6), G. macrorrhizum (7), M. officinalis (8), A. archangelica aerial part (9), A. archangelica root (10), T. vulgaris (11), H. officinalis (12), N. cataria (13), E. purpurea (14), S. officinalis (15), D. canadence (16) 


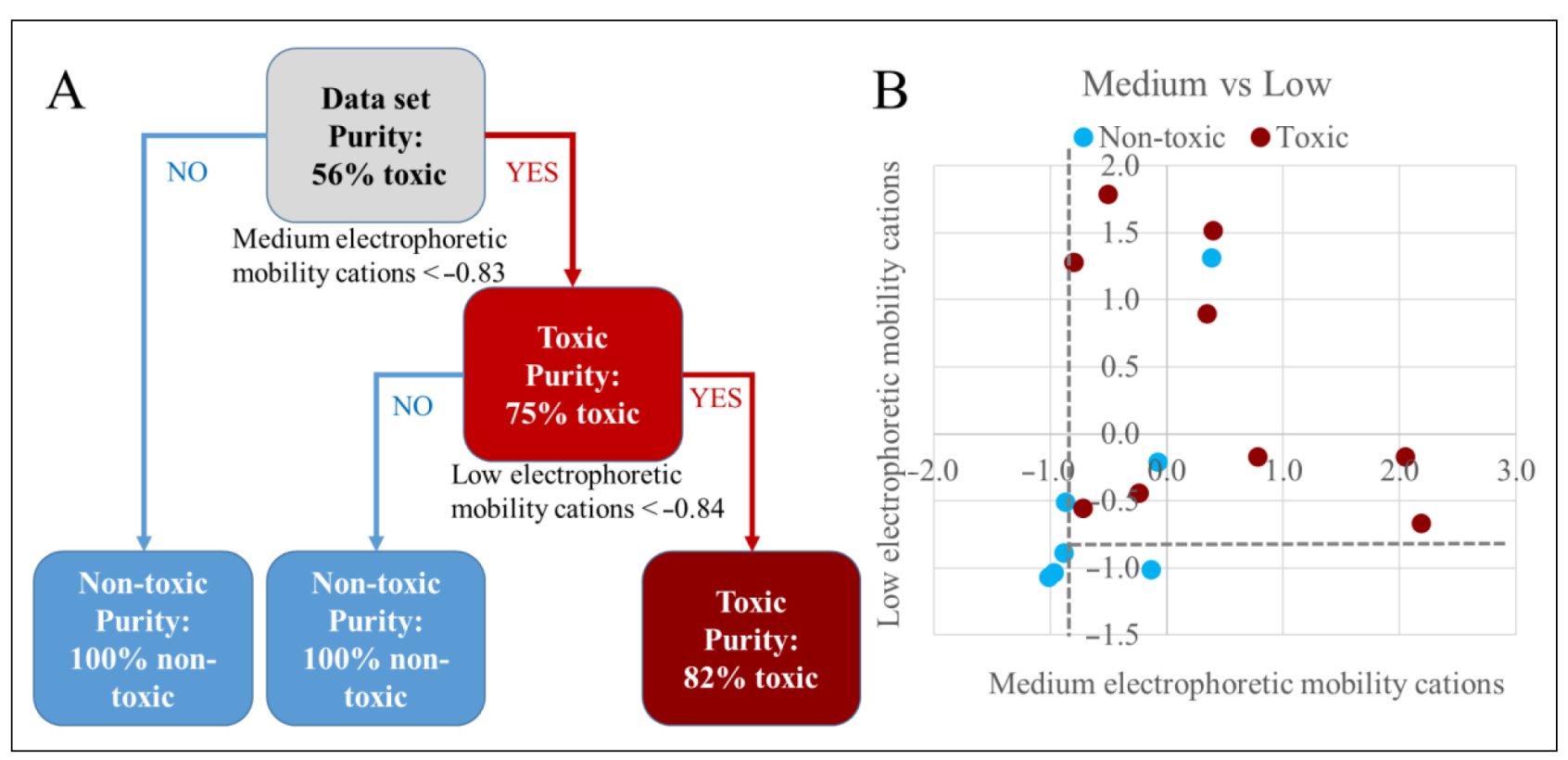

Fig. 4. Representation of the generated CART decision tree. (A) CART decision tree, (B) separation surface of the generated CART decision tree. A grey dashed line shows the rule generating surface

electrophoretic mobility cations have a higher normalized value than -0.83 , the extract is cytotoxic with a probability of $75 \%$. If (ii) the extract in the second level has the normalized value of low electrophoretic mobility cations lower than -0.84 , the extracts are non-cytotoxic. If low electrophoretic mobility cations have a higher normalized value than -0.84 , the extract is cytotoxic with a probability of $82 \%$. The normalized value of -0.83 of medium electrophoretic mobility cations corresponds to the $0.018 \mathrm{pF} \cdot \mathrm{s}$ absolute value of the peak area in the segment of medium electrophoretic mobility cations. And the normalized value of -0.84 of low electrophoretic mobility cations corresponds to the $0.019 \mathrm{pF} \cdot \mathrm{s}$ absolute value of the peak area in the segment of low electrophoretic mobility cations.

In Fig. $A \mathrm{~B}$ the rule generating surface is represented (a grey dashed line). It is visible that low concentrations of medium and low electrophoretic mobility cations are expected in the non-cytotoxic extracts.

In the previous work it was clarified that antiviral extracts possessed phenolic compounds with radical scavenging activity and medium and low electrophoretic mobility cations were found to be at low concentrations. This work shows a clear tendency that the cytotoxic extracts have abundant concentrations of medium and low electrophoretic mobility cations. Such observations should be taken into account designing new antiviral phyto-pharmaceutical products and natural virus prevention measures.

\section{CONCLUSIONS}

This study shows that: (i) the medium electrophoretic mobility cations are related to the cytotoxic activity of the plant extracts, (ii) the low electrophoretic mobility cati- ons are related to the cytotoxic activity of the plant extracts, (iii) the phenolic compounds possessing radical scavenging activity are expected to be at low concentrations in cytotoxic extracts.

\section{ACKNOWLEDGEMENTS}

The research was granted by the Research Council of Lithuania, Project No. MIP-065/2015. The Milton Roy Spectronic 1201 Spectrophotometer was a donation of Alexander von Humboldt Foundation. The capillary electrophoresis system HP3DCE was kindly donated by Dr. Gerard Rozing and Dr. Hans-Peter Schiefer (Agilent Technologies, Germany).

Received 20 March 2018 Accepted 5 April 2018

\section{References}

1. Z. Hussain, H. E. Thu, A. N. Shuid, P. Kesharwani, S. Khan, F. Hussain, Biomed. Pharmacother., 93, 596 (2017).

2. S. Chandra, D. S. Rawat, Integr. Med. Res., 4, 123 (2015).

3. S. A. El-Toumy, J. Y. Salib, W. A. El-Kashak, C. Marty, G. Bedoux, N. Bourgougnon, Food Sci. Hum. Wellness, 7(1), 91 (2018). DOI: 10.1016/J.FSHW.2018.01.001.

4. L. Kristanc, S. Kreft, Food Chem. Toxicol., 92, 150 (2016).

5. N. Tamilselvan, T. Thirumalai, P. Shyamala, E. David, J. Acute Dis., 3, 85 (2014).

6. L. Ranjbar, J. P. Foley, M. C. Breadmore, Anal. Chim. Acta, 950, 7 (2017).

7. Y. Jiang, M.-Y. He, W.-J. Zhang, et al., Chinese Chem. Lett., 28, 1640 (2017).

8. J. Haggarty, K. E. Burgess, Curr. Opin. Biotechnol., 43, 77 (2017). 
9. P. Kubáň, D. Štěrbova, V. Kubáň, Electrophoresis, 27, 1368 (2006).

10. V. Kaškonienė, A. Maruška, I. Akuṇeca, et al., Nat. Prod. Res., 30, 1373 (2016).

11. A. Maruška, R. Ugenskienė, D. Raulinaityte, et al., $A d v$. Med. Sci., 62, 158 (2017).

12. E. Alpaydin, Introduction to Machine Learning, 1st edn., Vol. 1107, Cambridge University Press, Cambridge (2014).

13. M. Wesołowski, B. Suchacz, Anal. Bioanal. Chem., 371, 323 (2001).

14. C. Ruiz-Samblás, J. M. Cadenas, D. A. Pelta, L. CuadrosRodríguez, Anal. Bioanal. Chem., 406, 2591 (2014).

15. G. Kaur, H. Monga, Int. J. Comput. Sci. Inf. Technol. Secur., 2, 2249 (2012).

16. T. Drevinskas, G. Naujokaitytè, A. Maruška, et al., Carbohydr. Polym., 173, 269 (2017).

17. T. Drevinskas, R. Mickiene, A. Maruška, et al., Anal. Methods, 10, 1875 (2018). DOI: 10.1039/C8AY00318A.

18. T. Drevinskas, M. Kaljurand, A. Maruška, Electrophoresis, 35, 2401 (2014).

19. T. Drevinskas, A. Maruška, V. Briedis, Electrophoresis, 36, 292 (2015).

20. A. Trivellini, M. Lucchesini, R. Maggini, et al., Ind. Crops Prod., 83, 241 (2016).

21. T. Drevinskas, V. Bartkuvienè, A. Maruška, Chemija, 25, 206 (2014).

22. V. Kaškoniene, M. Stankevičius, T. Drevinskas, et al., Phytochemistry, 115, 184 (2015).

23. T. Mosmann, J. Immunol. Methods, 65, 55 (1983).

24. RStudio Team (2015).

25. T. Therneau, B. Atkinson, B. Ripley, M. B. Ripley, rPart: Recursive Partitioning and Regression Trees, $\mathrm{R}$ Package Version 4.1-9 (2015).

26. P. J. F. Groenen, I. Borg, The Past, Present, and Future of Multidimensional Scaling, Econometric Institute Report
EI 2013-07, Econometric Institute, Erasmus School of Economics (ESE), Erasmus University Rotterdam (2013).

27. ICH Topic Q2 (R1). Validation of Analytical Procedures: Text and Methodology (2005).

28. I. Borg, P. Groenen, J. Stat. Softw., 31, 1 (2009).

Tomas Drevinskas, Rūta Mickienė, Audrius Maruška, Mantas Stankevičius, Nicola Tiso, Algirdas Šalomskas, Raimundas Lelešius, Agneta Karpovaitė, Ona Ragažinskienė

\section{AUGALŲ, TURINČIŲ POLIFENOLINIŲ IR LAKIỤ JUNGINIŲ BEI PASIŽYMINČIŲ PRIEŠVIRUSINIU POVEIKIU, CITOTOKSINIAI POŽYMIAI}

Santrauka

Natūralių produktų pritaikymas ịvairių ligų gydymui ir prevencijai tampa vis svarbesnis. Kuriami ne tik antibakteriniai natūralūs preparatai, bet tiriamos ir natūralios antivirusinès priemonès. Tyrimuose išskiriamos dvi pagrindinès problemos: (1) būtina naudoti specialius cheminès analizès ir duomenų analizès metodus ir (2) svarbūs ne tik antivirusiniai veiksniai, bet reikia atkreipti demesị ir $\mathfrak{i}$ citotoksinius bei kitus nepageidaujamus poveikius. Darbe aprašytas skirstymo metodų (kapiliarinè elektroforezè ir dujų chromatografija), spektrofotometrinių metodų, duomenų išgavimo / duomenų analizès metodų (hierarchinè klasterizacija, daugiadimensinès skalès keitimas ir klasifikacijos bei regresijos medžiu indukcija) pritaikymas aiškinantis, kokie cheminiai procesai augalų ekstraktuose yra atsakingi už citotoksini poveikį. Tyrimui parinkti augalai, priklausantys: notrelinių, graižažiedžių ir pupinių šeimoms. Citotoksiškiausi buvo Agastache foeniculum Pursh. Kuntze. ir Salvia officinalis L. ekstraktai. Mažiausiai citotoksiški - Perilla frutescens L.ir Satureja montana L. ekstraktai. Išaiškinta tendencija, kad citotoksiškai aktyvūs ekstraktai turi reikšmingas vidutiniškai ir lètai elektroforetiškai migruojančių katijonų koncentracijas. 